\title{
Performance of Jatropha Oil-based Biodiesel Fuel in a Single-cylinder Four-Stroke Diesel Engine
}

\author{
H. H. WIN
}

\begin{abstract}
Studies on alternative fuels have been active in Myanmar because the rapid mechanization of the agricultural sector demands higher diesel consumption. Jatropha oil-based biodiesel is one of the potential alternatives because of the relative ease of growing and producing this plant. In this study, both the experimental and theoretical analyses of Jatropha oil-based B20 biodiesel were performed and compared with conventional diesel. First, B20 was prepared by the base-catalyzed transesterification of the oil and its properties were measured. Second, separate performance tests were conducted on diesel and the biodiesel fuel using a LEYER-16 diesel engine. The speed range of interest was between 1000 r.p.m and 2000 r.p.m. Third, performance simulations were done in MATLAB using an algorithm written based on the theory of the engine operating cycle and air/ fuel compositions. Both experimental and simulation results show that there were no significant differences in the brake power and thermal efficiency of the engine between using diesel and the B20 diesel. However, fuel consumption when using B20 was slightly higher than that of diesel. This difference was marginal and it can be concluded that engine performance characteristics are the same for both diesel and B20 suggesting that B20 has great potential to be used as a substitute for diesel.
\end{abstract}

Key words: Jatropha biodiesel; B20 biodiesel; alternative fuel; diesel engine performance; biofuel; experimental and theoretical analyses

The agriculture sector in Myanmar is completely dependent on diesel for its motive power. Increased farm mechanization in agriculture has also further increased the use of diesel fuel. As diesel is relatively expensive, the search for alternative fuels has been active in Myanmar. Many alternative fuels like biogas, methanol, ethanol and vegetable oils have been evaluated as a partial or complete substitute for diesel. Vegetable oils can be used directly in a diesel engine as a fuel, because their calorific value is almost equal to that of diesel. Therefore, several studies and research groups in Myanmar have focused attention on the technologies to produce, collect and extract vegetable oil from different oil seeds such as Jatropha.
Jatropha oil is non-edible oil and has a comparable cetane number to diesel; hence no major modification in the diesel engine is necessary when it is used. Moreover, it is relatively safe to store, handle and transport Jatropha oil because its initial flash point $\left(110^{\circ} \mathrm{C}\right)$ is higher than that of $\operatorname{diesel}\left(50^{\circ} \mathrm{C}\right)$. Therefore, compared with edible vegetable oils, Jatropha oil is an ideal alternative fuel to diesel. To promote the use of Jatropha oil, Myanmar is speeding up the growing of the Jatropha plant. Several studies and research on biodiesel have also been conducted by several government organizations in Myanmar, such as the Ministry of Industry 1, the Ministry of Industry 2, and the Department of Farm

Department of Mechanical Engineering, Mandalay Technological University, Myanmar Corresponding author (e-mail: htayhtayw@gmail.com) 
Machinery of the Ministry of Science and Technology (Kywe \& Oo 2009).

The objective of this study is to investigate the performance of a biodiesel blend (B20) and compare it with that of diesel in a conventional diesel engine through experimental and theoretical studies. Performance tests were conducted using a single-cylinder, four-stroke diesel engine. This study will provide answers as to whether biodiesel could be used as an alternative to diesel and provide the guidelines for converting the diesel engine to a biodiesel engine.

\section{MATERIALS AND METHODS}

\section{Biodiesel Fuel}

Biodiesel blend B20 (80\% diesel, 20\% Jatropha biodiesel) was prepared by base-catalyzed transesterification. The transesterification process with methanol consisted of two steps: (i) esterification of the fatty acids of crude Jatropha oil ( $8.8 \%$ of FFA) into refined Jatropha oil and (ii) transesterification of neutral glycerides mixture into methyl ester by adding methanol and $\mathrm{KOH}$ as catalysts through washing and filtration (Figure 1). The esterification process was carried out at $75^{\circ} \mathrm{C}$ to $100^{\circ} \mathrm{C}$ in a standard atmosphere. In the transesterification process, methanol was used to deactivate lipase enzymes and this took $12 \mathrm{~h}$ to $15 \mathrm{~h}$. Finally, pure biodiesel was obtained as a clear amber-yellow liquid. The properties of B20 are shown in Table 1.

\section{Engine}

The engine used in this study was a $\mathrm{S} 1100$ LY-16 diesel engine and its specifications are shown in Table 2.
$\mathrm{CH}_{2}$ OOR<smiles>CCOO</smiles>

$\mathrm{CH}_{2} \mathrm{OOR}$
$\mathrm{CH}_{2} \mathrm{OH}$<smiles>COC(=O)[C+](C)O</smiles>

$\mathrm{CH}_{2} \mathrm{OH}$

\section{$\begin{array}{llll}\text { Triglyceride } & \text { Methanol } & \text { Methyl Ester } & \text { Glycerol }\end{array}$}

Figure 1. Principle of transesterification reaction with methanol.

Table 1. Properties of diesel oil, Jatropha oil and Jatropha biodiesel. ${ }^{\mathrm{a}}$

\begin{tabular}{l|ccc}
\hline \multicolumn{1}{c|}{ Property } & Diesel & Jatropha oil & Jatropha biodiesel \\
\hline Density $\left(\mathrm{gm} / \mathrm{cc}\right.$ at $\left.30^{\circ} \mathrm{C}\right)$ & 0.84 & 0.93 & 0.85 \\
Kinematic viscosity $\left(\mathrm{cSt}\right.$ at $\left.30^{\circ} \mathrm{C}\right)$ & 3.6 & 42 & 4.5 \\
Cetane number & $40-55$ & $38-51$ & 50 \\
Flash point $\left({ }^{\circ} \mathrm{C}\right)$ & $45-80$ & $110-240$ & 170 \\
Calorific value $(\mathrm{MJ} / \mathrm{kg})$ & $42-46$ & $38-42$ & 38 \\
Sulphur $(\%)$ & $1.0-1.2$ & 0.13 & 0 \\
Carbon residue $(\%)$ & 0.1 & 0.64 & 0.5 \\
\hline
\end{tabular}

a Hoa et al. 
Table 2. S1100 LY-16 diesel engine specifications.

\begin{tabular}{l|c}
\hline \multicolumn{1}{c|}{ Type } & $\begin{array}{c}\text { Single-cylinder, } \\
\text { four-stroke, horizontal }\end{array}$ \\
\hline Cylinder bore (mm) & 100 \\
Piston stroke (mm) & 115 \\
Compression ratio & 20 \\
Fuel consumption (gal/hr) & 0.55 \\
Output power (kW) & 11.03 \\
Rated speed (r.p.m) & 2200 \\
Piston displacement (litre) & 0.903 \\
\hline
\end{tabular}

\section{Experiment Method}

A schematic diagram of the experimental setup is shown in Figure 2. Before the performance test, proper operation of the test engine was ensured. The performance characteristics of the engine using diesel and B20 were quantified by measuring fuel consumption and brake torque at various operating speeds. Before each measurement, steady operation of the engine was ensured. Rotational speed of the engine $(N)$ was measured by a tachometer with the use of reflective tape on the crankshaft. The speed was varied in 100 r.p.m increments from 1000 to 2000 . Fuel consumption $\left(m_{f}\right)$ was measured by recording the initial and instantaneous volume of the fuel. The fuel tank was attached to a graduated burette. The valve at the bottom of the tank was closed when fuel consumption rate was to be measured so that the fuel was consumed only from the burette. The time taken for the fuel to be consumed was recorded to measure the fuel consumption rate.

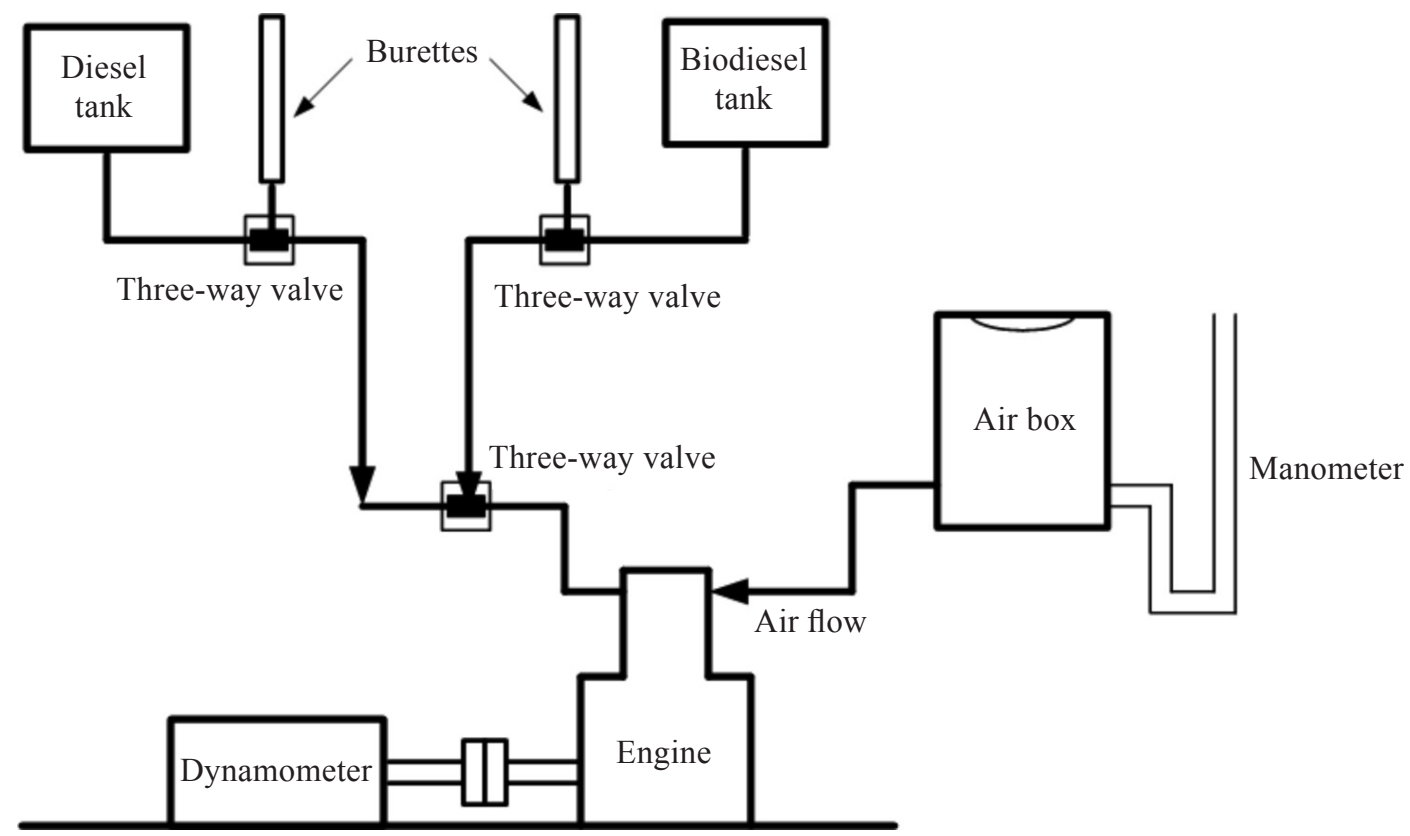

Figure 2. Experimental setup. 
Engine torque measurements were performed with a dynamometer at speeds from 1000 to 2000 r.p.m. The engine was clamped to the floor. Then, the engine shaft was connected to the dynamometer rotor. Engine torque on the rotor was measured by balancing the stator with known weights $(W)$ at known distances $(D)$. Brake power $(B P)$ was calculated from the measured engine torque (Pulkrabek 1988).

$$
B P=\frac{\pi D W N}{60}
$$

Torque and power were recorded for each speed increment to determine brake specific fuel consumption (bsfc), and brake thermal efficiency can then be computed if the calorific value of the fuel $(\mathrm{CV})$ is known.

Break thermal efficiency $=\frac{B P}{m_{\nu} C V}$

\section{Theoretical Model}

A theoretical model of the engine performance was constructed based on the theory of the engine operating cycles: intake, compression, combustion and expansion (Heywood 1988). An algorithm was written to calculate the theoretical brake power, specific fuel consumption and thermal efficiency for both diesel and B20 fuels (khovakh 1971). The flow chart for this algorithm is shown in Figure 3.

\section{RESULTS AND DISCUSSION}

\section{Experimental Results}

Figure 4 shows the variations in brake power at full load as a function of operating speed for both B20 and diesel. It was observed that brake power increased with speed for both diesel and B20. Moreover, the rate of brake power increment with speed was lower for speeds above 1500 r.p.m. This may be due to the fact that friction losses at higher speeds were relatively more dominant than at lower speeds. However, it must be noticed that the brake power of the engine had not achieved its maximum value compared with typical diesel engines (Pulkrabek 1988). Most diesel engines have a maximum brake power at engine speeds of approximately 6000 r.p.m. to 7000 r.p.m. However, brake power measurements in this study were performed in the speed range of only 1000 r.p.m. to 2000 r.p.m. Therefore, in order to compare the maximum brake powers of engines with diesel and B20, it is suggested that more studies be performed to measure brake power at higher speeds of up to 6000 r.p.m. However, based on the existing results with some limitations, it can be concluded qualitatively that the engine running on B20 had almost equal available brake power to that of the diesel-run engine although brake power with diesel was slightly larger.

Figure 5 shows the variations in brake specific fuel consumptions at different engine speeds for both B20 and diesel. At all speeds, the brake specific fuel consumption for B20 was approximately $2 \%$ higher than that for diesel fuel. At speeds below 1200 r.p.m., the consumptions of both fuels decreased with speed. This decrement in fuel consumption with speed has also been reported in a study by Nematullah (2010) although the speed range in that study was different from this study. As speed increased, the consumptions of both fuels increased, as was also shown in the previous study (Nematullah 2010). However, at speeds above 1900 r.p.m., the rate of fuel consumption of B20 was higher than that of diesel. One of the possible reasons for this discrepancy could be experimental error due to incorrect timing between speed increment and load increment as this experiment was controlled manually. Engine speeds may have fluctuated whenever the load was increased or decreased.

Figure 6 shows engine brake thermal efficiency as a function of engine speed. The range of brake thermal efficiencies for both diesel and B20 was between 30 and 37. This result is comparable to the brake thermal 


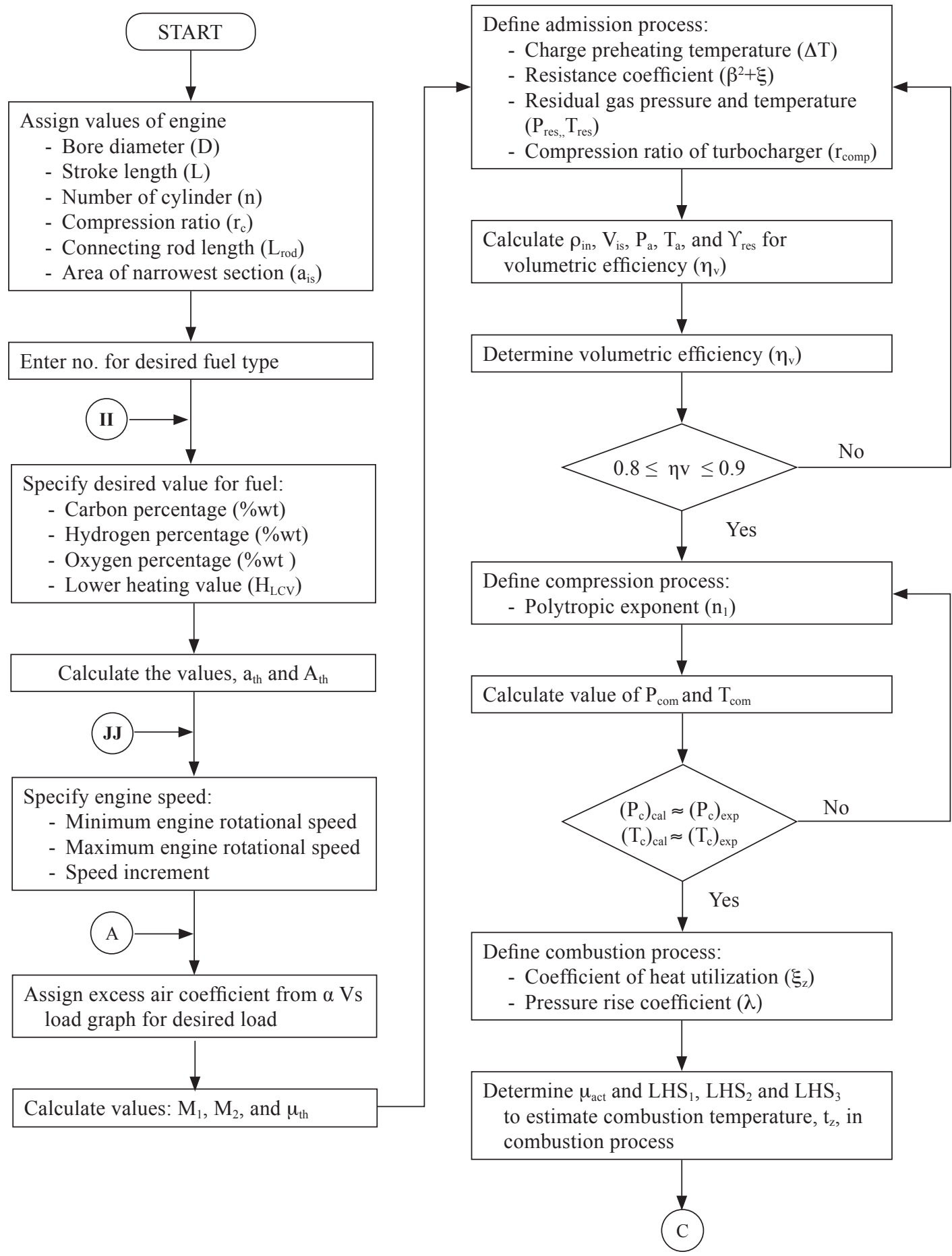

Figure 3. Flow chart for estimating theoretical performance by simulation. 


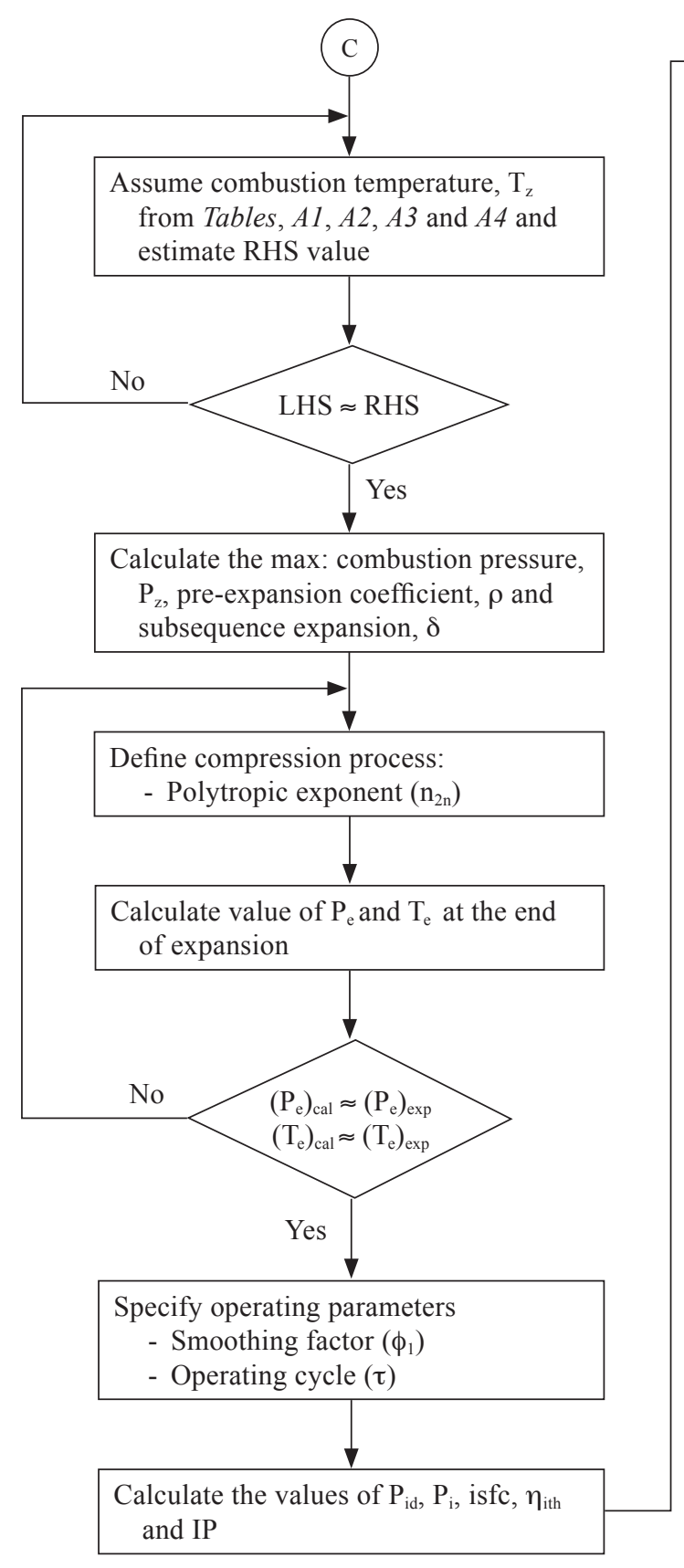

Set the values of A and B from Table $A .5$ and determine, $\mathrm{V}_{\mathrm{p}}$

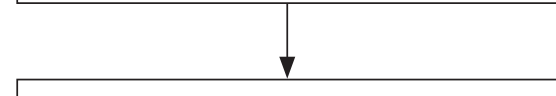

Calculate the values of $P_{b}, \eta_{\text {mech }}$, bsfc, $\eta_{\text {bth }}, \mathrm{BP}$ and $\mathrm{m}_{\mathrm{f}}^{\circ}$
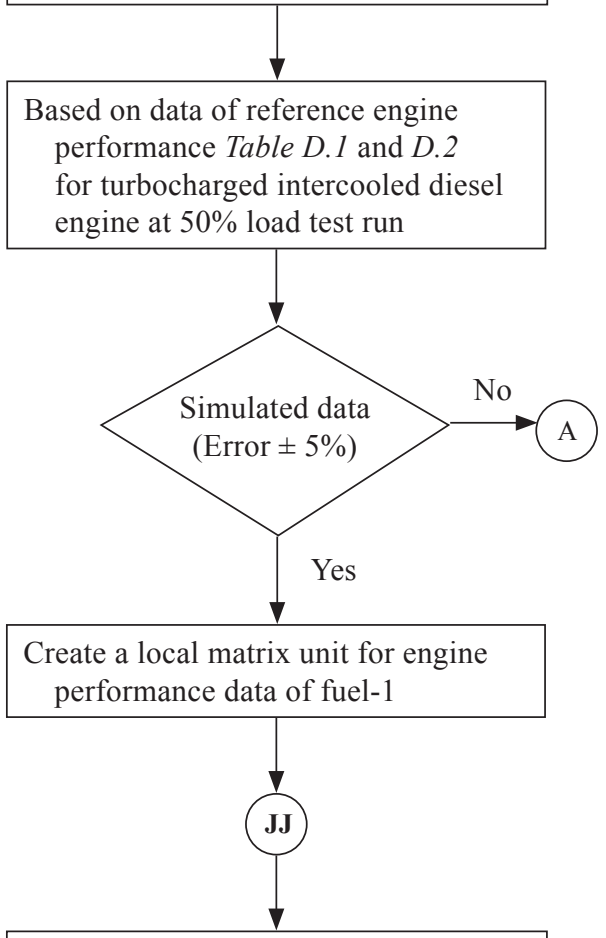

Create an external matrix unit for all fuel types in engine operating range

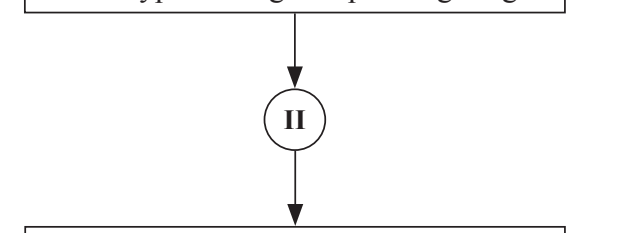

Compare performance results of fuel-1, fuel-2, etc. and plot the simulated results against engine speed in the form of tables and graphs

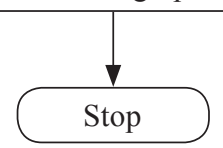

Figure 3 (Cont.). Flow chart for estimating theoretical performance by simulation. 


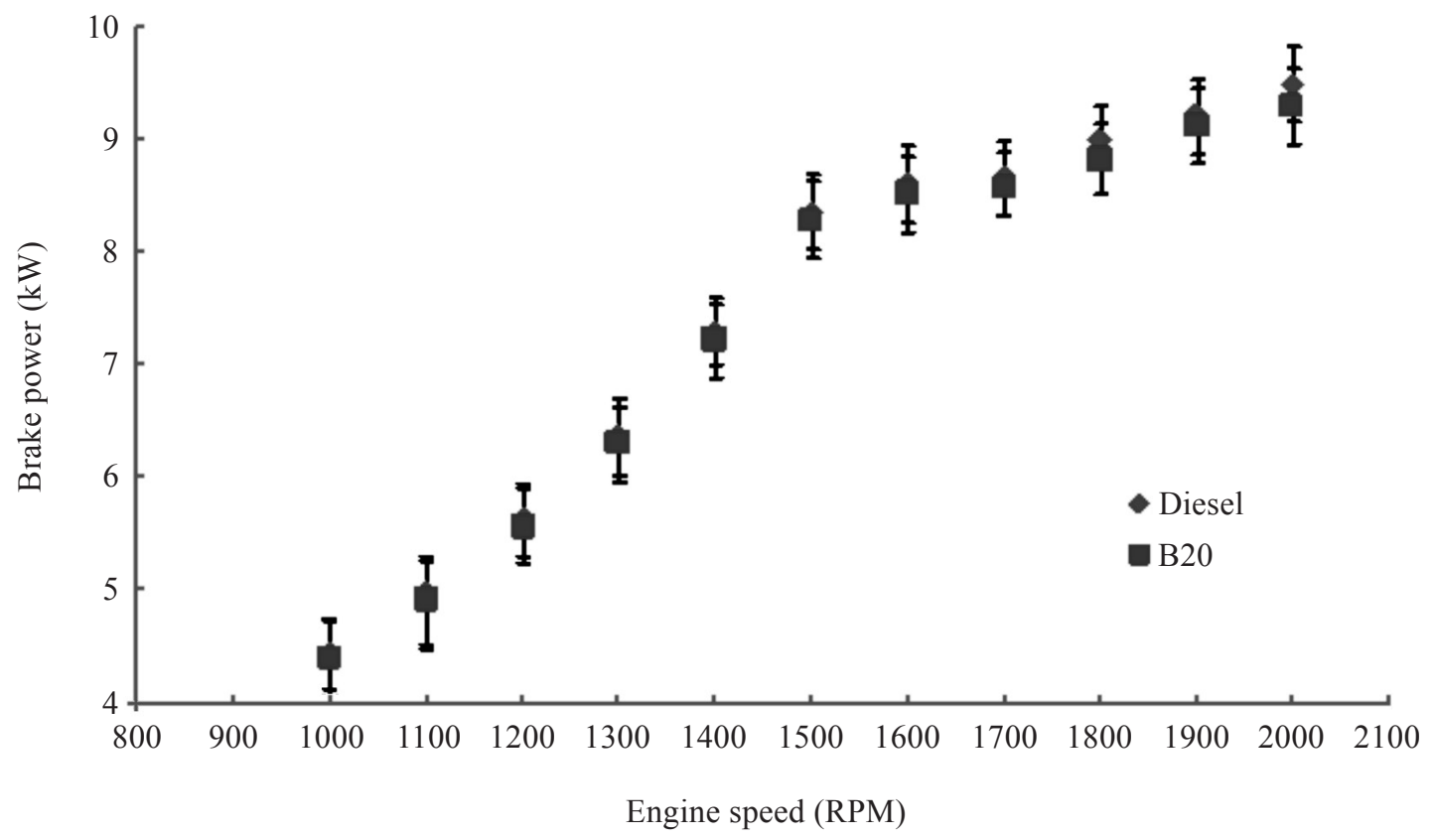

Figure 4. Comparison of engine brake power with different fuels.

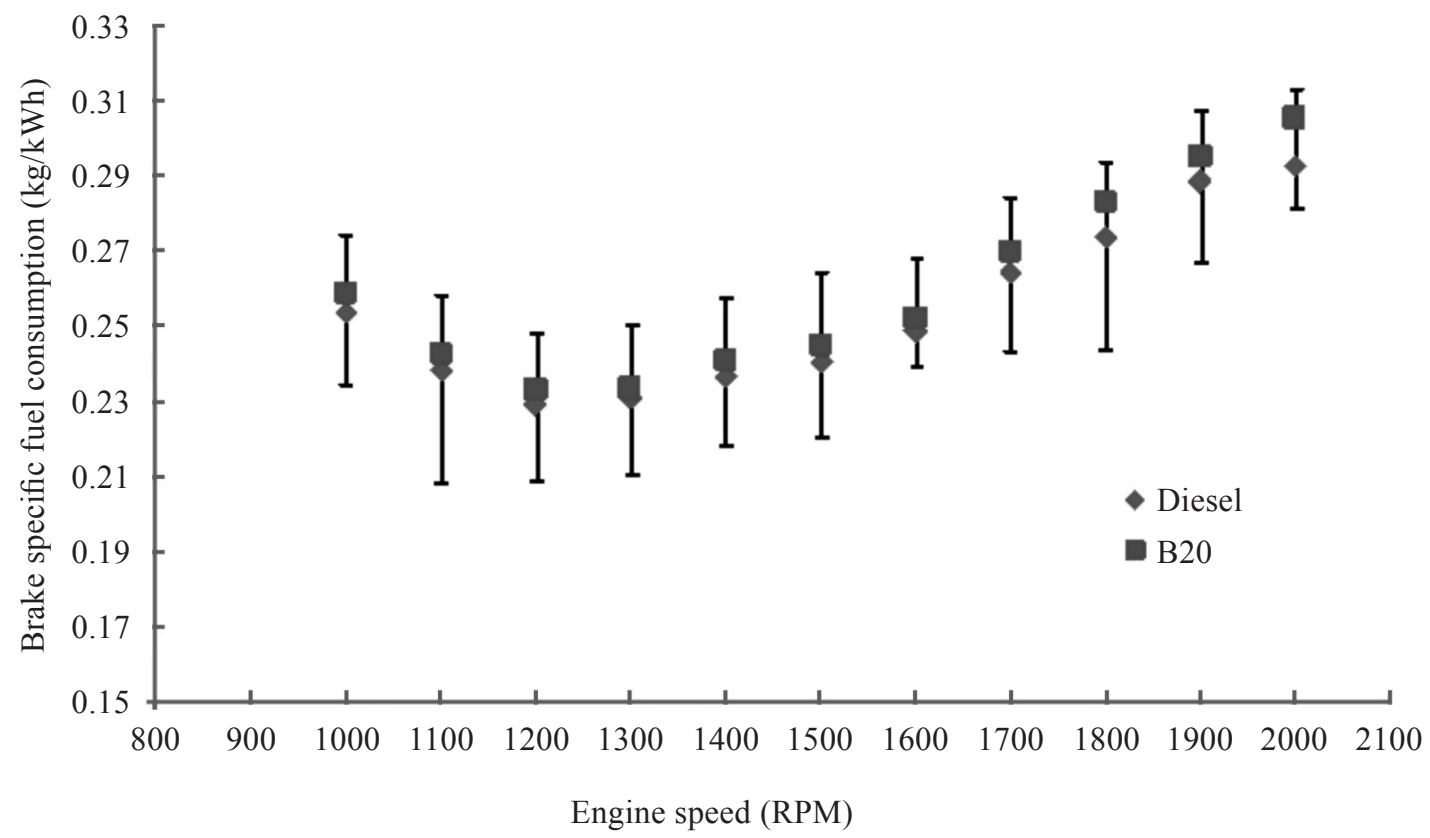

Figure 5. Comparison of engine brake specific fuel consumption with different fuels. 


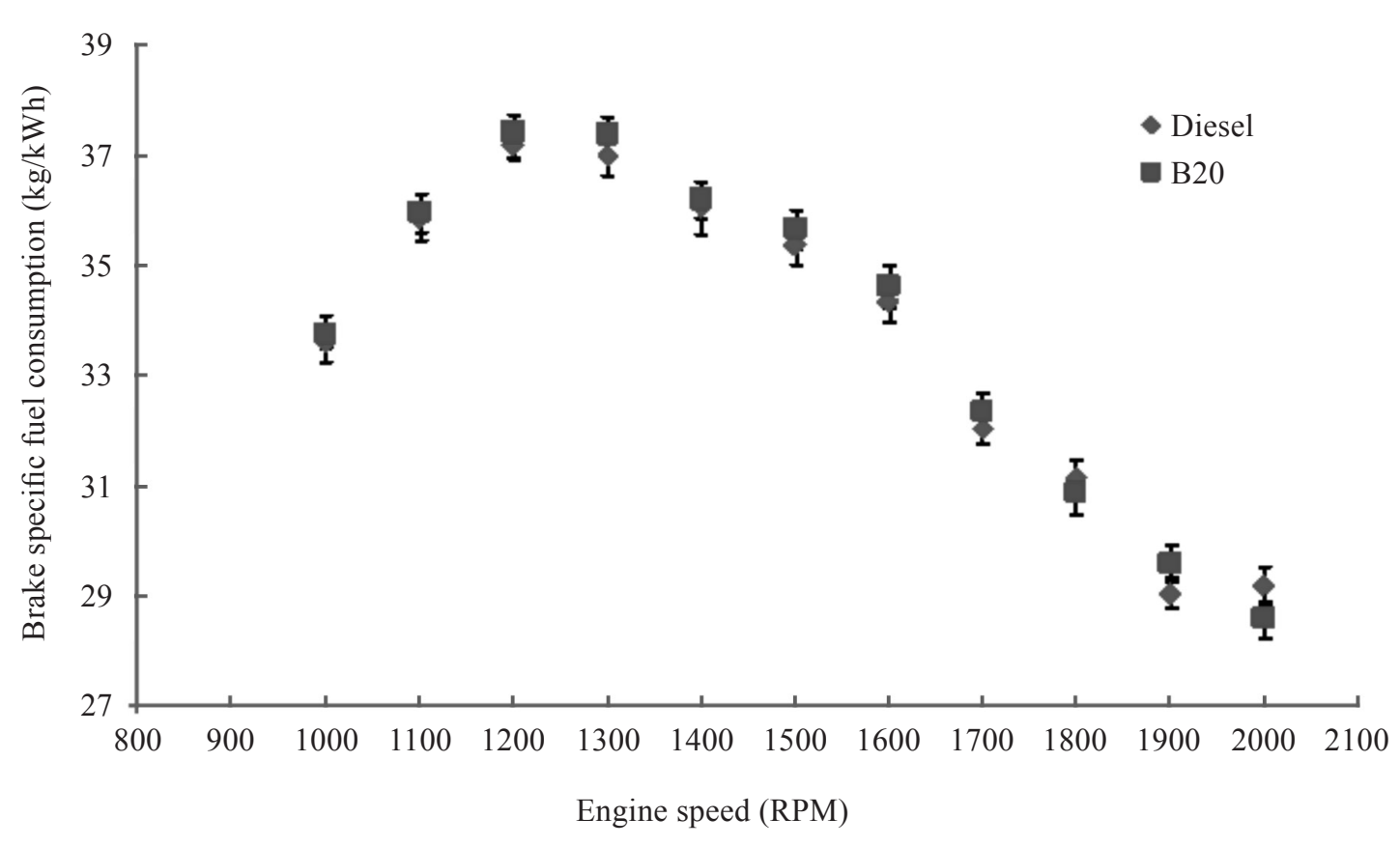

Figure 6. Comparison of engine brake thermal efficiency with different fuels.

efficiency range for B20 reported in literature (Nematullah 2010). It can also be seen that, as expected, the brake thermal efficiency was inversely proportional to the specific fuel consumption (Figure 5). It is also observed that there was no significant difference in the brake thermal efficiencies when using the conventional diesel fuel and B20 biodiesel both at low and high speeds. This result was expected because the calorific value of B20 (41.24 MJ/ $\mathrm{kg}$ ) was close to that of diesel $(42.2 \mathrm{MJ} / \mathrm{kg})$. Therefore, B20 can be used as a substitute for diesel fuel. Another advantage with B20 is that unlike other biodiesels such as B100, no combustion deposits on valve, piston crown, cylinder head and injector were observed after a long period of operation.

\section{Simulation Results}

Figure 7 shows the experimental and simulation brake powers for both diesel and B20 fuels. The experimental and simulation brake powers were similar in trend for both diesel and B20 fuels. For diesel, the maximum error between the experimental and simulation results was approximately $7 \%$ although the maximum error for B20 was around 1\%. However, the simulation results also showed that brake power with diesel was slightly higher than that with B20, which is in agreement with the experimental results shown in Figure 4, suggesting again that B20 can be used as a substitute for diesel.

Similar trends between experimental and simulation results for brake specific fuel consumption and thermal efficiency were also observed as shown in Figure 8 and Figure 9. In Figure 8 , the maximum error in brake specific fuel consumption between experiments and simulations was around $1 \%$ with both diesel and B20. The maximum error in thermal efficiency was also around $1 \%$ with both diesel and B20. Therefore, overall, the experimental results were in good agreement with the simulation results. The simulation results in Figure 8, which were in agreement with the experimental results, 


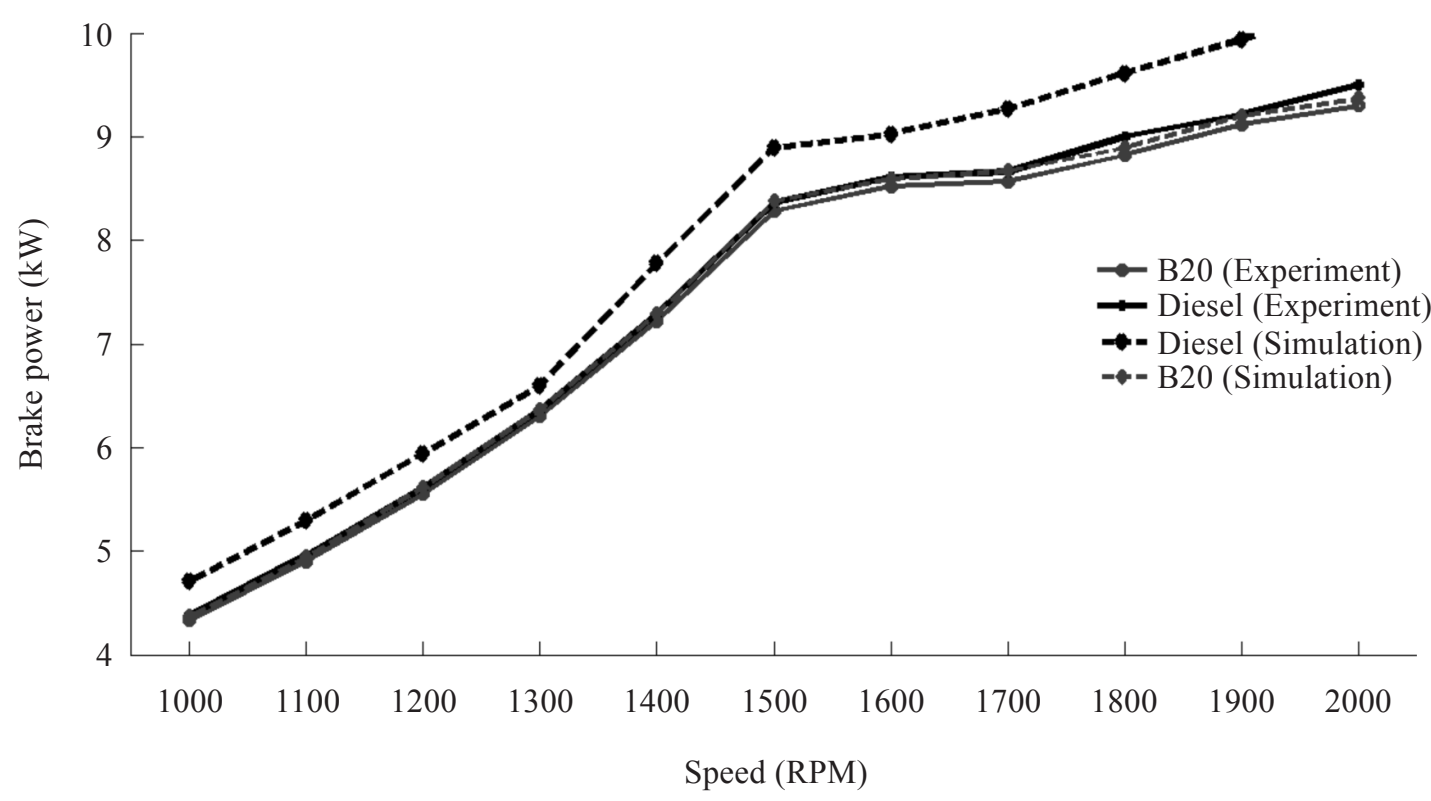

Figure 7. Comparison between experiments and simulations in engine brake power.

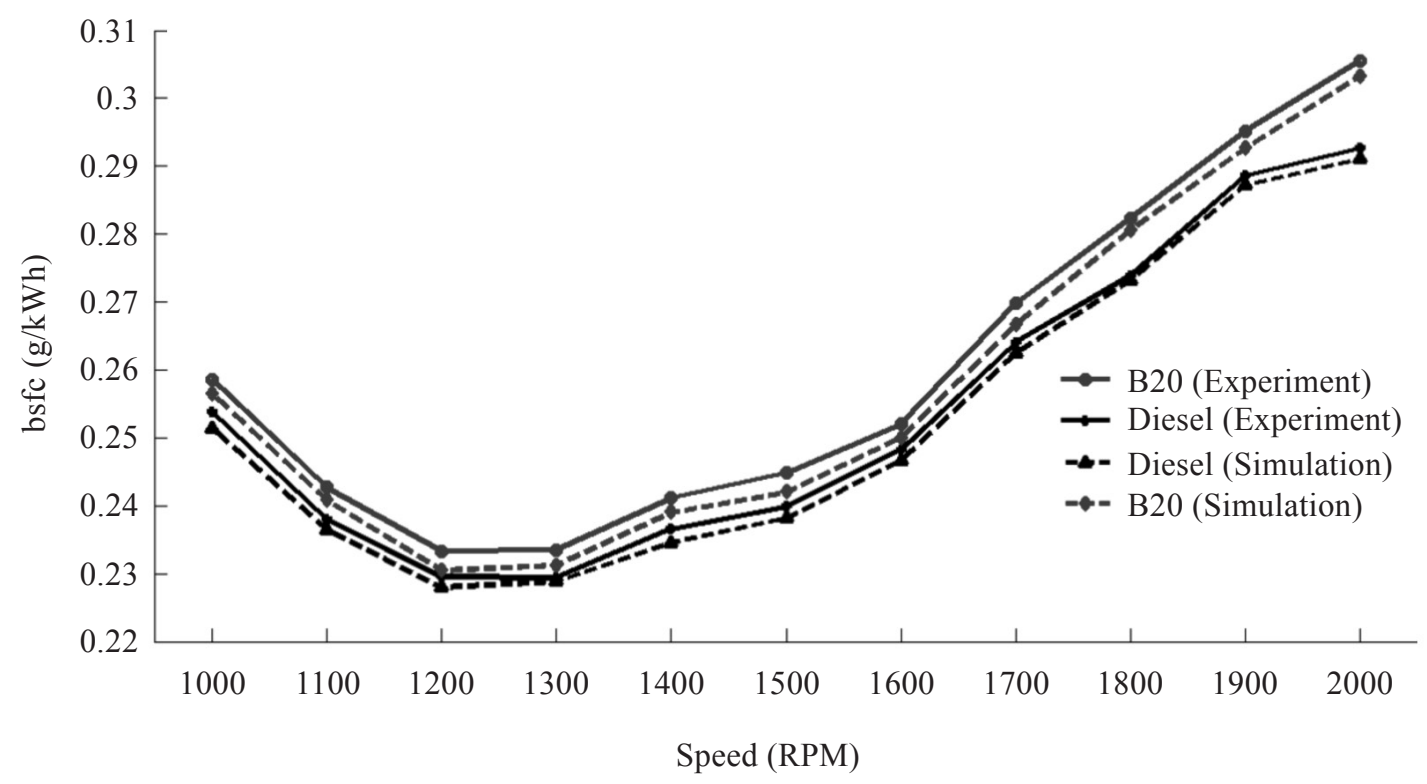

Figure 8. Comparison between experiment and simulation: specific fuel consumption. 


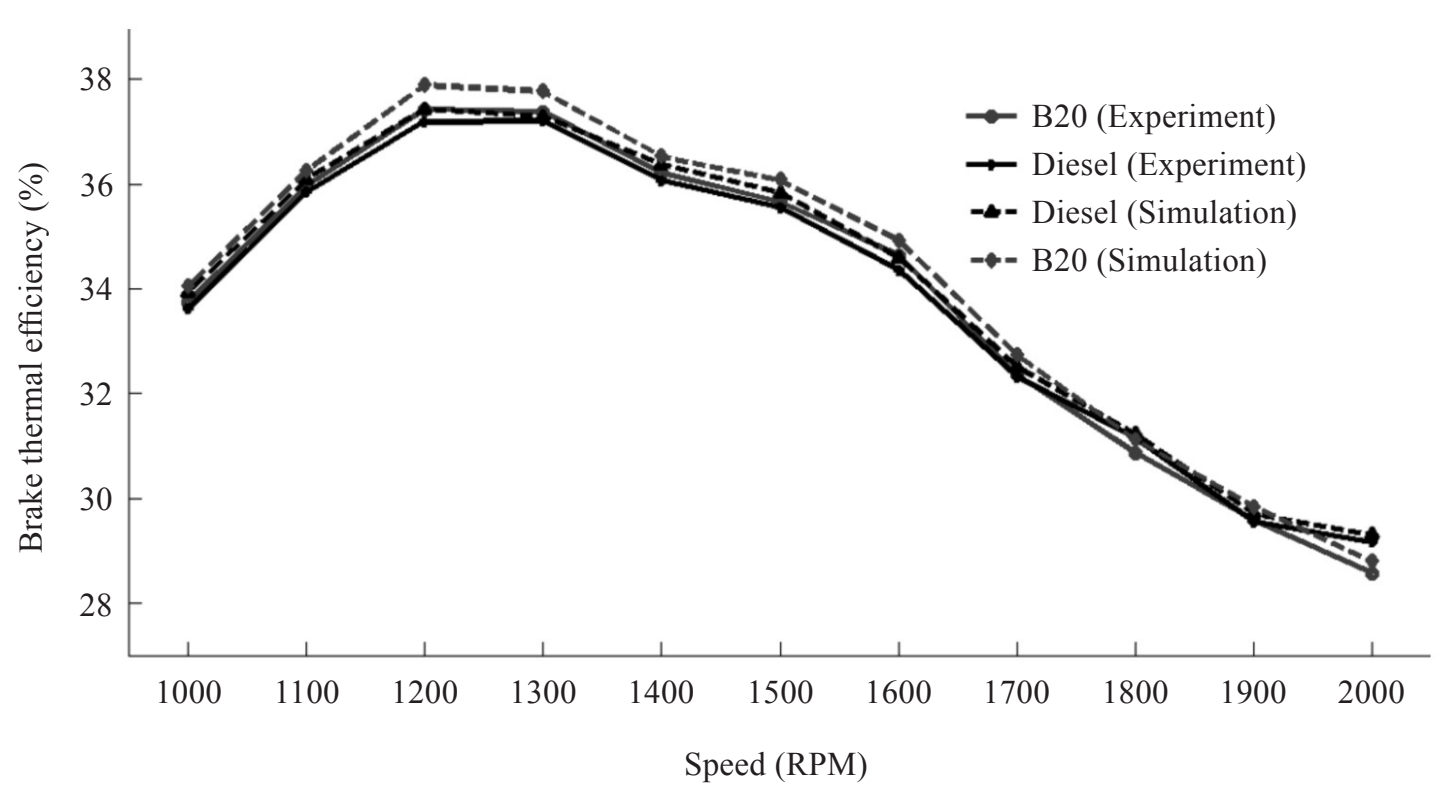

Figure 9. Comparison between experiments and simulations in brake thermal efficiency.

suggest that brake specific fuel consumption with B20 was slightly higher than that with diesel. The simulation results in Figure 9 also suggest that there was no significant difference in brake thermal efficiency between using diesel and B20 supporting the experimental findings in Figure 6.

\section{CONCLUSIONS}

The performance of biodiesel blend B-20 was tested in a single-cylinder four-stroke indirect injection diesel engine. It was found, during the experiments, that the use of B-20 fuel did not require any additional modification to the engine and that it could operate smoothly with no notable problems. Based on the experimental analysis on brake power, specific fuel consumption and thermal efficiency, it can be concluded that B-20 can perform almost as efficiently as diesel fuel. This result is in line with the results reported in literature (Hoa 2012; Forson et al. 2004; Baitiang et al.
2008). Therefore, Jatropha oil-based diesel fuel has great potential to replace conventional diesel fuel. Apart from the experimental analyses, a theoretical model which can represent the performance of a compression ignition engine was also built and verified with the experimental findings for both diesel and B20 fuels. However, the experimental performance data were collected within limited engine speeds. In order to fully investigate the performance of B20 at higher engine speeds, more experimental studies should be done on engines with higher rated speeds.

Date of submission: August 2012

Date of acceptance: September 2012

\section{REFERENCES}

BAITIANG, T et al. 2008, 'Effects of biodiesel and Jatropha oil on performance, black smoke and durability of single-cylinder diesel engine', Journal of Metals, Materials and Minerals, vol. 18, no. 2, pp. 181-185. 
Forson, FK et al. 2004, 'Performance of Jatropha oil blends in a diesel', Renewable Energy, vol. 29, pp. $1135-1145$.

Heywood, JB 1988, Internal combustion engine fundamentals, International Edition, Mcgraw Hill, London.

Hoa, DT et al. 2012, 'The Potential Jatropha curcas for agriculture and forest diesel engine in Vietnam', International Conference on Environment, Energy and Biotechnology, IPCBEE 33, pp. 7-11.

Khovakh, M 1971, Motor vehicle engines, MIR Publishers, Moscow.
Kywe, TT \& Oo, MM 2009, 'Production of biodiesel from Jatropha oil (Jatropha Curcas) in Pilot Plant', World Academy of Science, Engineering and Technology, no. 26, pp. 477-483.

Nasim, MN et al. 2010, 'Simulation of CI engine powered by neat vegetable oil under variable fuel inlet temperature', Indian Journal of Science and Technology, vol. 3, no. 4, pp. 387-392.

Pulkrabek, WW 1988, Engineering fundamentals of the internal combustion engine, Prentice Hall, New Jersey, pp. 35-68. 